\title{
PRÓBA LIKWIDACJI STATUSU „ARCHIWÓW PAŃSTWOWYCH WYODRĘBNIONYCH" W PROJEKCIE USTAWY - PRAWO ARCHIWALNE Z 1995 R.
}

Słowa kluczowe: prawo archiwalne, likwidacja archiwów państwowych wyodrębnionych

\section{Streszczenie}

Celem artykułu jest przedstawienie procedowania projektu ustawy - Prawo archiwalne z $1995 \mathrm{r}$. w zakresie likwidacji statusu „archiwów państwowych wyodrębnionych” (obecnie „archiwów wyodrębnionych"), zwłaszcza w kontekście oporu ze strony Ministerstwa Spraw Wewnętrznych. Przedmiotem sporu była wówczas szczególnie kwestia wprowadzenia przez Naczelnego Dyrektora do Spraw Archiwalnych RP pozaresortowego nadzoru i kontroli nad archiwami wydzielonymi, zwłaszcza archiwami resortu spraw wewnętrznych (w tym służb specjalnych). Studium wskazuje skalę i dynamikę międzyinstytucjonalnego sporu, w który zaangażowane były Ministerstwo Edukacji Narodowej i Naczelna Dyrekcja Archiwów Państwowych z jednej strony, a Ministerstwo Spraw Wewnętrznych, Ministerstwo Obrony Narodowej i Ministerstwo Spraw Zagranicznych z drugiej. Ostatecznie - pomimo prób mediacji w ramach Urzędu Rady Ministrów i Komitetu SpołecznoPolitycznego Rady Ministrów - nie udało się wypracować kompromisowego stanowiska, a sam projekt ustawy nie wszedł $\mathrm{w}$ życie. Przedmiotowe studium wskazuje ponadto różnice stanowisk i wzajemnych wyobrażeń środowisk archiwów państwowych w konfrontacji z kręgami archiwów wyodrębnionych, właściwych zwłaszcza w zakresie zapewnienia bezpieczeństwa wewnętrznego państwa. 
PIOTR BORYSIUK

ORCID $0000-0002-2357-5929$

piotr.borysiuk@gmail.com

(National Police Headquarters, Main Archive of Police)

\title{
AN ATTEMPT TO REMOVE THE STATUS OF "SEPARATED STATE ARCHIVES” IN THE BILL ON ARCHIVES 1995
}

Keywords: bill on archives, removal of separated state archives

\begin{abstract}
The objective of the article is to present the processing of the Bill on Archives of 1995 by focusing on the removal of the "separated state archive" status (currently "separated archives"), especially in the context of the resistance of the Ministry of the Interior. The conflict was related to an issue that was especially important at the time: the introduction of non-ministry supervision and control over separated archives, especially archives of the department of the interior (including special services), by the General Director for Polish Archives. The study shows the scale and the dynamics of the crossinstitutional dispute, which involved the Ministry of Education and the Head Office of State Archives on one side and the Ministry of the Interior, the Ministry of National Defense and the Ministry of Foreign Affairs on the other. Ultimately, despite attempts at mediation within the Office of the Council of Ministers and the Social and Political Committee of the Council of Ministers, no compromise was reached and the bill was never enacted. The study also identifies the dissents, related in particular to homeland security, between the circles representing national archives and the environment of the separated archives, and presents how they perceived each other.
\end{abstract}


Status ,archiwów państwowych wyodrębnionych”, wprowadzony ustawą z dnia 14 lipca 1983 r. o narodowym zasobie archiwalnym i archiwach ${ }^{1}$, w środowiskach archiwów państwowych i akademickich znajduje liczne grono krytyków oraz przeciwników jego istnienia ${ }^{2}$. Niniejszy artykuł - oparty na materiałach archiwalnych przechowywanych w Archiwum Rady Ministrów oraz Archiwum Zakładowym Naczelnej Dyrekcji Archiwów Państwowych - podejmuje próbę opisania tego podejścia w roku 1995, kiedy to, w ramach procedowania projektu ustawy - Prawo archiwalne, podjęto nieudaną próbę likwidacji wymienionego statusu. Autorem przedmiotowego studium jest jednakże pracownik jednego z archiwów wyodrębnionych, mający kilkunastoletnią praktykę, niepodzielający poglądów archiwistów sfery cywilnej na zasadność istnienia i funkcjonowania tego rodzaju placówek ${ }^{3}$.

W 1995 r. - na podstawie art. 29 unza - funkcjonowało de facto kilkadziesiąt archiwów wyodrębnionych. Były to archiwa: Prezydenta RP, Sejmu, Senatu, Ministerstwa Spraw Zagranicznych (dalej: MSZ) oraz dwie rozległe sieci archiwów wyodrębnionych, tj. wojskowa sieć archiwalna oraz sieć archiwalna resortu spraw wewnętrznych. Pierwszą z nich tworzyły Centralne Archiwum Wojskowe (dalej: CAW) oraz jego filie w postaci Archiwum Instytucji Centralnych Ministerstwa Obrony Narodowej, Archiwum Warszawskiego Okręgu Wojskowego, Archiwum Pomorskiego Okręgu Wojskowego, Archiwum Śląskiego Okręgu Wojskowego, Archiwum Marynarki Wojennej, Archiwum Wojsk Lotniczych i Obrony Powietrznej oraz Archiwum Krakowskiego Okręgu Wojskowego, jak również - nieujęte w wojskowej sieci archiwalnej - Archiwum Wojskowych Służb Informacyjnych. Z kolei sieć archiwalną resortu spraw wewnętrznych (dalej: rsw) tworzyły Centralne Archiwum Ministerstwa Spraw Wewnętrznych (dalej: MSW) oraz archiwa Urzędu Ochrony Państwa (dalej: UOP), Policji, Straży Granicznej, Państwowej Straży Pożarnej, Nadwiślańskich Jednostek Wojskowych, Biura Ochrony Rządu, Centralnego Zarządu Służby Zdrowia MSW oraz jednostek badawczych rsw i przedsiębiorstw, dla których Minister Spraw Wewnętrznych był organem założycielskim ${ }^{4}$.

${ }^{1}$ Ustawa z dnia 14 lipca 1983 r. o narodowym zasobie archiwalnym i archiwach (Dz.U. 1983, nr 38, poz. 173, z późn. zm.) - dalej: unza. W ramach jednej z kolejnych nowelizacji unza przeprowadzonej w 2007 r. - na podstawie ustawy z dnia 2 marca 2007 r. o zmianie ustawy o narodowym zasobie archiwalnym i archiwach (Dz.U. 2007, nr 64, poz. 426) - status „,archiwów państwowych wyodrębnionych” zmieniono na ,archiwa wyodrębnione”.

2 Zob. zwł.: R. Galuba, Archiwa wyodrębnione w państwie demokratycznym, [w:] Nowa archiwistyka - archiwa i archiwistyka w ponowoczesnym kontekście kulturowym, Toruńskie konfrontacje archiwalne, t. 4, red. W. Chorążyczewski, W. Piasek i A. Rosa, Toruń 2014, s. 119-136 oraz idem, Archiwa wyodrębnione. Wybór przepisów z lat 2000-2011, Poznań 2013, s. 9-55.

${ }^{3}$ O funkcjonowaniu archiwów wyodrębnionych, zob.: P. Borysiuk, Specyfika funkcjonowania archiwów wyodrębnionych w Polsce - aspekty prawno-historyczne i strukturalne. Zarys problematyki, [w:] Studia. Materiały. Konferencje Stowarzyszenia Archiwistów Polskich, nr 8: Archiwa wyodrębnione w polskiej sieci archiwalnej, praca zbiorowa pod red. A. Jabłońskiego, Szczecin 2020, s. 19-85.

${ }^{4}$ Ibidem, s. 33-40. Tu szczegółowa literatura przedmiotu i akty prawne sankcjonujące funkcjonowanie poszczególnych archiwów wyodrębnionych w tamtym czasie. 
Dla rozważań niniejszego - studium zwłaszcza w kontekście sieci archiwalnej MSW - kluczowym jest uchwycenie kontekstu społeczno-politycznego lat 90. XX w., który ogniskował się wokół sporu o lustrację oraz kwestii otwarcia archiwów byłego komunistycznego MSW ${ }^{5}$. Należy przy tym podkreślić, iż czas procedowania projektu ustawy - Prawo archiwalne z 1995 r. jest zasadniczo ostatnim momentem przed wprowadzeniem poważnych zmian w polskim systemie archiwalnym, zapoczątkowanych projektami ustaw z lat 1997 (projekt ustawy o utworzeniu Archiwum Obywatelskiego oraz o powszechnym udostępnianiu dokumentacji wytworzonej w latach 1944-1990 przez organy bezpieczeństwa państwa) ${ }^{6}$ i 1998 (projekt ustawy o Instytucie Pamięci Narodowej) ${ }^{7}$, co w konsekwencji doprowadziło do powstania Instytutu Pamięci Narodowej - Komisji Ścigania Zbrodni przeciwko Narodowi Polskiemu oraz nadania archiwom IPN statusu wyodrębnionego ${ }^{8}$. W pierwszej połowie lat 90. $\mathrm{XX}$ w. rozpoczęto dopiero wypracowywanie rekomendacji w zakresie dostępu obywateli do dokumentacji tajnych służb bezpieczeństwa państw reżimów totalitarnych i autorytarnych ${ }^{9}$.

Projekt ustawy - Prawo archiwalne opracowywany był od 1990 r., kiedy to, na wniosek Naczelnego Dyrektora Archiwów Państwowych, Rada Archiwalna

${ }^{5}$ Zob. przekrojowo: P. Grzelak, Wojna o lustrację, Warszawa 2005, s. 15-142 oraz D. Koczwańska-Kalita, (Nie)chciane dziecko III RP. Instytut Pamięci Narodowej 2000-2010. Geneza, funkcjonowanie, kontekst społeczny i polityczny, Kraków 2015, s. 18 i nast.

${ }^{6}$ Droga legislacyjna: druk nr 31 - Przedstawiony przez Prezydenta Rzeczypospolitej Polskiej projekt ustawy o utworzeniu Archiwum Obywatelskiego oraz o powszechnym udostępnianiu dokumentacji wytworzonej w latach 1944-1990 przez organy bezpieczeństwa państwa, http://orka.gov.pl/ proc3.nsf/opisy/31.htm [dostęp: 19.07.2020].

${ }^{7}$ Droga legislacyjna: druk nr 252 - Rządowy projekt ustawy o Instytucie Pamięci Narodowej, http://orka.sejm.gov.pl/proc3.nsf/opisy/252.htm [dostęp: 19.07.2020].

${ }^{8}$ Ustawa z dnia 18 grudnia 1998 r. o Instytucie Pamięci Narodowej - Komisji Ścigania Zbrodni przeciwko Narodowi Polskiemu (Dz.U. 1998, nr 155, poz. 1016, z późn. zm.).

9 W latach 1994-1995 międzynarodowa grupa ekspertów, pracująca z inicjatywy Konferencji Okrągłego Stołu Międzynarodowej Rady Archiwów w Meksyku z 1993 r., dokonywała analizy zagadnień związanych z archiwami służb bezpieczeństwa państw reżimowych. Raport podsumowujący prace tego zespołu z 1995 r., zob.: A. Gonzalez Quintana, Archives of the security services of former repressive regimes. Report prepared for UNESCO on behalf of the International Council of Archives, „Janus” 1998, nr 2, s. 7-25. Raport zamieszczono również na stronie internetowej UNESCO: idem, Archives of the security services of former repressive regimes. Report prepared for UNESCO on behalf of the International Council of Archives, Paris 1997, https://unesdoc.unesco.org/ark:/48223/pf0000140074 [dostęp: 19.07.2020]. W polskiej literaturze przedmiotu na ten temat, zob.: W. Stępniak, UNESCO na rzecz dostępu obywateli do akt tajnych stużb państw represyjnych, „Archiwista Polski” 2000, nr 2(18), s. 51 i n. Ponadto zob.: A. Gonzalez Quintana, Archival policies in the protection of human rights. An updated and fuller version of the report prepared by UNESCO and the International Council on Archives (1995), concerning the management of the archives of the state security services of former repressive regimes, Paris 2009, https://www.ica.org/sites/default/files/Report_Gonzalez-Quintana_EN.pdf [dostęp: 19.07.2020]. 
powołała komisję, która zakończyła swe prace we wrześniu 1993 r. ${ }^{10} \mathrm{~W}$ kolejnym roku, na podstawie decyzji nr 42 Ministra Edukacji Narodowej z dnia 18 lipca 1994 r. w sprawie powołania Zespołu do spraw prac związanych z przygotowaniem projektu ustawy - Prawo archiwalne, powołano siedmioosobową grupę pod przewodnictwem Naczelnego Dyrektora Archiwów Państwowych, prof. Jerzego Skowronka. Celem zespołu było przygotowanie projektu ustawy oraz zaopiniowanie aktów wykonawczych do niej ${ }^{11}$.

W efekcie tych prac przygotowano projekt nr II ustawy - Prawo archiwalne, który, pismem z 14 lutego 1995 r., Ministerstwo Edukacji Narodowej (dalej: MEN) rozesłało do kilkudziesięciu podmiotów, celem zaopiniowania, z propozycją przeprowadzenia konferencji uzgodnieniowej wszystkich zainteresowanych. W skrócie projekt zakładał:

1) powołanie państwowej administracji archiwalnej, nad którą zwierzchni nadzór sprawować miał Prezes Rady Ministrów (art. 6 ust. 1-2 projektu II);

2) określenie, iż centralnym organem administracji państwowej właściwym w sprawach archiwalnych miał być Naczelny Dyrektor do Spraw Archiwalnych RP (art. 6 ust. 3 projektu II);

3) udostępnianie materiałów archiwalnych ,po upływie 30 lat od ich wytworzenia, jeżeli nie narusza to prawnie chronionych interesów Rzeczypospolitej Polskiej lub interesów osób fizycznych i prawnych" (art. 24 ust. 2 projektu II);

4) utworzenie państwowych archiwów bieżących (archiwów instytucji), gdzie czasowo będą przechowywane materiały archiwalne oraz państwowych archiwów historycznych (centralnych i okręgowych), stanowiących samodzielne jednostki organizacyjne, w których materiały archiwalne będą przechowywane na stałe (art. 20, 26-28 oraz 30 projektu II);

5) przekazywanie przez państwowe archiwa bieżące materiałów archiwalnych do państwowych archiwów historycznych „nie później niż po upływie 30 lat od ich wytworzenia, chyba że przepisy szczegółowe przewidują dłuższe okresy ich przechowywania lub nie ustały okoliczności uzasadniające przechowywanie tych materiałów w archiwach bieżących" (art. 29 ust. 2 projektu II);

6) wykonywanie merytorycznego nadzoru archiwalnego nad państwowymi archiwami bieżącymi przez Naczelnego Dyrektora ${ }^{12}$.

${ }^{10}$ Naczelna Dyrekcja Archiwow Państwowych, Archiwum Zakładowe (dalej: AZ NDAP), 486/5 Naczelna Dyrekcja Archiwów Państwowych (dalej: NDAP), Wydział Organizacji i Planowania (dalej: WOiP), uzasadnienie do projektu II ustawy - Prawo archiwalne, stanowiącego załącznik do pisma DP-0151-74/94/MJ Ministra Edukacji Narodowej (w zastępstwie ministra podsekretarz stanu) z dnia 14.02.1995 r., s. 22.

${ }^{11}$ Ibidem, decyzja Ministra Edukacji Narodowej z dnia 18 VII 1994 r. w sprawie powołania Zespołu do spraw prac związanych z przygotowaniem projektu ustawy - Prawo archiwalne, s. 116-117.

${ }_{12}$ Ibidem, projekt II ustawy - Prawo archiwalne, s. 7-16. Szerzej o założeniach do projektu ustawy - Prawo archiwalne, zob.: A. Biernat, Ustawodawstwo archiwalne w świetle przeobrażeń praw- 
Kwestię archiwów państwowych wyodrębnionych regulował art. 51, który przez następne miesiące budził ostre spory międzyinstytucjonalne. W punkcie wyjściowym sprowadzał się on do niniejszej postaci:

„1. Archiwa państwowe wyodrębnione, istniejące w dniu wejścia w życie ustawy, stają się archiwami państwowymi bieżącymi, spełniającymi jednocześnie zadania archiwów historycznych w zakresie określonym w art. 28 ust. 2 pkt. $1 \mathrm{w}$ odniesieniu do materiałów historycznych, dotyczących danej instytucji, przechowywanych w dniu wejścia w życie ustawy oraz wytworzonych po tej dacie, z zastrzeżeniem ust. 2.

2. Centralne Archiwum Wojskowe staje się z dniem wejścia w życie ustawy centralnym państwowym archiwum historycznym. Uprawnienia Naczelnego Dyrektora określone w art. $31 \mathrm{w}$ stosunku do Centralnego Archiwum Wojskowego wykonuje Minister Obrony Narodowej w porozumieniu z Naczelnym Dyrektorem. Naczelny Dyrektor sprawuje nad Centralnym Archiwum Wojskowym merytoryczny nadzór archiwalny, którego zakres i tryb określa, w drodze rozporządzenia, Prezes Rady Ministrów.

3. Organy państwowe prowadzące archiwa, o których mowa w ust. 1 wydadzą w ciągu sześciu miesięcy od dnia wejścia w życie ustawy, w porozumieniu z Naczelnym Dyrektorem, regulaminy tych archiwów, uwzględniające przepisy ustawy"13.

Do projektu załączono protokół rozbieżności, w którym wyrażono sprzeciw przedstawicieli MSW i MSZ w zakresie brzmienia art. 51, którzy wprost stwierdzili, że „nie można przyjąć koncepcji likwidacji archiwów wyodrębnionych, dla których Ministrowie: Spraw Zagranicznych i Spraw Wewnętrznych są właściwymi organami administracji państwowej"14. Ponadto MSW sprzeciwiło się zapisom o nadzorze Naczelnego Dyrektora nad działalnością archiwów bieżących stwierdzając, iż jest to „daleko idącym ograniczeniem kompetencji MSW w zakresie zarządzania zasobami archiwalnymi resortu" 15 . Jednocześnie rsw zgłosił zastrzeżenia do brzmienia art. 24 zauważając, iż oznacza to „uprawnienie dyrektorów archiwów państwowych do decydowania o udostępnieniu materiałów archiwalnych mających znaczenie dla realizacji zadań Policji lub UOP”"16.

noustrojowych w Polsce, [w:] Archiwa Europy Środkowej i Wschodniej w dobie przeksztatceń prawnoustrojowych. Materiaty międzynarodowej konferencji archiwalnej 28-30 czerwca 1996 r. w Putawach, red. B. Woszczyński przy udziale E. Rosowskiej, Warszawa 1997, s. 46-49.

${ }_{13}$ AZ NDAP, 486/5 NDAP, WOiP, art. 51 ust. 1-3 projektu II ustawy - Prawo archiwalne, s. 20.

${ }_{14}$ Ibidem, Protokół rozbieżności do projektu ustawy - Prawo archiwalne [bez daty], s. 34.

15 Ibidem, s. 33.

${ }^{16}$ Ibidem, s. 31. Oprócz brzmienia art. 24 ust. 2, projekt zakładał, iż dyrektorzy archiwów historycznych będą mogli odmówić udostępniania materiału ,jeżeli jego udostępnienie mogłoby spowodować naruszenie interesu publicznego lub ważnego interesu osobistego, a także w przypadku, gdy stan fizyczny materiału nie pozwala na jego udostępnienie". Zob.: ibidem, art. 24 ust. 4 projektu II ustawy - Prawo archiwalne, s. 12-13. 
Efektem przeprowadzonej w dniu 27 lutego 1995 r. konferencji uzgodnieniowej było uzgodnienie stanowisk przy jednoczesnym podtrzymaniu dwóch zasadniczych rozbieżności, które poskutkowały opracowaniem przez MEN dwóch wariantów ich zapisu. W związku z tym Minister Edukacji Narodowej przesłał do Komitetu Społeczno-Politycznego Rady Ministrów zmodyfikowany projekt ustawy - Prawo archiwalne oraz cztery projekty aktów wykonawczych:

- rozporządzenie Prezesa Rady Ministrów w sprawie szczegółowych zasad postępowania $\mathrm{z}$ dokumentacją wytwarzaną $\mathrm{i}$ gromadzoną przez organy państwowe, organy samorządu terytorialnego, zawodowego lub gospodarczego, państwowe jednostki organizacyjne oraz organy partii politycznych:,

- rozporządzenie Prezesa Rady Ministrów w sprawie trybu przeprowadzania kontroli postępowania z materiałami archiwalnymi:

- zarządzenie Naczelnego Dyrektora do Spraw Archiwalnych Rzeczypospolitej Polskiej w sprawie ustalania opłat za udostępnianie materiałów archiwalnych przez archiwa państwowe i samorządowe:

- rozporządzenie Prezesa Rady Ministrów w sprawie zakresu i trybu merytorycznego nadzoru archiwalnego Naczelnego Dyrektora do Spraw Archiwalnych Rzeczypospolitej Polskiej nad działalnością państwowych archiwów bieżących ${ }^{17}$.

W art. 24. ust. 2 pierwszy wariant pozostawał bez zmian - tak jak opisano powyżej. Z kolei w wariancie drugim do zapisu pierwotnego dodano stwierdzenie, że „udostępnianie materiałów archiwalnych zawierających informacje stanowiące tajemnicę państwową lub służbową albo dane indywidualne zebrane na zasadach określonych o statystyce państwowej może nastąpić po spełnieniu warunków oraz w trybie określonych w przepisach odrębnych" 18 .

$\mathrm{W}$ art. 51 pierwszy wariant zapisu pozostał niezmienny, jednak w drugim wariancie zmodyfikowano treść brzmienia art. 51 ust. 1 do postaci:

„1. Archiwa państwowe wyodrębnione, istniejące w dniu wejścia w życie ustawy, stają się archiwami państwowymi bieżącymi, spełniającymi jednocześnie zadania archiwów historycznych w zakresie przechowywania historycznych materiałów dotyczących danej instytucji, z zastrzeżeniem ust. 2"19.

Zastrzeżenie znowu poczyniono dla CAW, które miało stać się centralnym państwowym archiwum historycznym. Niemniej archiwalny nadzór merytoryczny nad tymi archiwami miał sprawować Naczelny Dyrektor ${ }^{20}$.

${ }^{17}$ Archiwum Rady Ministrów (dalej: ARM), 2963/5 Komitet Społeczno-Polityczny Rady Ministrów (dalej: KSPRM), pismo DP-0151-74/94/MJ Ministra Edukacji Narodowej do dyrektora Sekretariatu KSPRM z dnia 27.03.1995 r. wraz z załącznikami, bp.

18 Ibidem, Projekt ustawy - Prawo archiwalne przesłany za pismem DP-0151-74/94/MJ Ministra Edukacji Narodowej do dyrektora Sekretariatu KSPRM z dnia 27.03.1995 r., bp. [s. 8 projektu].

${ }^{19}$ Ibidem, bp. [s. 16 projektu].

${ }^{20}$ Ibidem. 
Projekt wywołał wiele uwag krytycznych, zwłaszcza ze strony Ministerstwa Finansów. Spośród organów państwowych, posiadających archiwa wyodrębnione, Ministerstwo Obrony Narodowej (dalej: MON) opowiedziało się za drugim wariantem brzmienia art. 24 ust. 2, stwierdzając przy tym jednocześnie, że „regulacje ujęte $\mathrm{w}$ wariantowo przedstawionym art. 51 - w stosunku do problematyki dotyczącej archiwistyki wojskowej - zawierają jednakową treść" i opowiedziało się ostatecznie za pierwszym wariantem brzmienia artykułu ${ }^{21}$.

Jednakże zasadniczy sprzeciw do propozycji MEN i NDAP złożyło MSW, które wniosło o nowe brzmienie art. 51 ust. $3 \mathrm{w}$ postaci:

„3. Archiwa resortu spraw wewnętrznych stają się z dniem wejścia w życie ustawy państwowymi archiwami bieżącymi, spełniającymi jednocześnie zadania archiwów historycznych. Uprawnienia Naczelnego Dyrektora w stosunku do archiwów resortu spraw wewnętrznych wykonuje Minister Spraw Wewnętrznych"22.

Stwierdzono, że „projekt ustawy jest daleko idącym ograniczeniem kompetencji Ministra Spraw Wewnętrznych w zakresie zarządzania zasobami archiwalnymi resortu”, podkreślając przy tym, iż „koncepcja ujednolicenia systemu archiwów i zasad postępowania z materiałami archiwalnymi nie może mieć całkowitego zastosowania w odniesieniu do archiwów resortu spraw wewnętrznych”. Zauważono jednocześnie, że „nie ma racjonalnego uzasadnienia dla rozszerzania kręgu osób, którym są udostępniane materiały archiwalne, w większości opatrzone klauzulą tajności (w tym materiały operacyjne)"23.

Dalej stwierdzano, że zapisy projektu ustawy - Prawo archiwalne kolidują z:

1) art. 7 ust. 2 ustawy z dnia 6 kwietnia 1990 r. o urzędzie Ministra Spraw Wewnętrznych ${ }^{24}$ oraz art. 12 ustawy z dnia 6 kwietnia 1990 r. o Urzędzie Ochrony Państwa ${ }^{25}$, które to przepisy określały, iż zabronione jest udzielanie informacji o obywatelu, uzyskanych w czasie wykonywania czynności operacyjno-rozpoznawczych, do wiadomości osób lub instytucji innych niż sąd i prokurator, a także wykorzystywanie ich przeciw obywatelowi w celu innym niż ściganie karne;

2) art. 2 ust. 1 pkt 2 ustawy z dnia 14 grudnia 1982 r. o ochronie tajemnicy państwowej i służbowej w zakresie ochrony danych identyfikujących funkcjonariuszy organów porząaku i bezpieczeństwa publicznego oraz

${ }^{21}$ Ibidem, pismo nr 207/4/95 zastępcy dyrektora Departamentu Prawnego Ministerstwa Obrony Narodowej z 11.04.1995 r., bp. [dokument nr 30 sprawy].

${ }^{22}$ Ibidem, pismo L-I-983/94 Ministra Spraw Wewnętrznych (w/z podsekretarz stanu Henryk Jasik) z 12.04.1995 r., bp. [dokument nr 18 sprawy]. Ponadto wniesiono, aby w ust. 1, po wyrazach „ust. 2”, skreślić kropkę i dodać zapis o treści „i ust. 3”.

${ }^{23}$ Ibidem, bp. [dokument nr 18 sprawy].

${ }^{24}$ Dz.U. 1990, nr 30, poz. 181.

${ }^{25}$ Dz.U. 1990, nr 30, poz. 180. Tożsamy zapis w art. 21 ust. 1 ustawy z dnia 6 kwietnia 1990 r. o Policji (Dz.U. 1990, nr 30, poz. 179). 
osób współdziałających z nimi, wykonujących zadania z zakresu wywiadu lub kontrwywiadu ${ }^{26}$.

MSW podkreśliło także, iż zapisy projektu rozporządzenia Prezesa Rady Ministrów w sprawie trybu przeprowadzania kontroli postępowania z materiałami archiwalnymi - upoważniające m.in. do kontroli gromadzenia, ewidencjonowania, przechowywania, opracowywania, zabezpieczania i udostępniania materiałów archiwalnych - będą umożliwiały „zapoznanie się ze szczegółową strukturą organizacyjną UOP, a w konsekwencji zapoznanie się z wiadomościami mającymi newralgiczne znaczenie dla pracy Urzędu" ${ }^{27}$. Dalej stwierdzano, że kontrola kompletności materiałów - realizowana po stwierdzeniu ich niekompletności także w innych, wewnętrznych jednostkach poszczególnych instytucji - w praktyce może doprowadzić do sytuacji, iż „po stwierdzeniu braków w teczce pracy prowadzonej przez oficera operacyjnego Zarządu Kontrwywiadu kontrolerzy udadzą się do Zarządu Kontrwywiadu, aby tam przeprowadzić poszukiwanie brakujących dokumentów" ${ }^{\prime 28}$. Z kolei uprawnienie do kontroli klasyfikacji i kwalifikacji archiwalnej „oznacza w praktyce możliwość zapoznania się z merytoryczną treścią dokumentacji operacyjnej oznaczonej klauzulą tajne spec. znaczenia, a więc dokumentacją mogącą mieć kluczowe znaczenie dla interesu bezpieczeństwa Państwa" ${ }^{29}$.

Podkreślano przy tym, że szczegółowe zapisy projektu rozporządzenia (kontrola stanu fizycznego i stopnia opracowania materiałów, kontrola poprawności środków ewidencyjnych, kontrola prawidłowości udostępniania materiałów) pozwalają kontrolerom na ,zapoznanie się z merytoryczną treścią dokumentacji, a w konsekwencji umożliwiają nabycie przez nich wiedzy, która umożliwiłaby naruszenie przepisów o ochronie tajemnicy państwowej oraz dóbr osobistych osób trzecich" ${ }^{30}$. W sposób szczególny podkreślano konsekwencje zapoznania się przez pozaresortowych kontrolerów z treścią dokumentów zawierających informacje stanowiące tajemnicę państwową lub służbową ${ }^{31}$.

W odniesieniu do projektu rozporządzenia Prezesa Rady Ministrów w sprawie szczegółowych zasad postępowania z dokumentacją wytwarzaną i gromadzoną przez organy państwowe, organy samorządu terytorialnego, zawodowego lub gospodarczego, państwowe jednostki organizacyjne

${ }^{26}$ Dz.U. 1982, nr 40, poz. 271, z późn. zm. Dla tego okresu zob. także uchwałę Trybunału Konstytucyjnego z dnia 13 VI 1994 r. w sprawie ustalenia powszechnie obowiązującej wykładni art. 2 ust. 1 pkt 2 ustawy z dnia 14 grudnia 1982 r. o ochronie tajemnicy państwowej i służbowej (Dz.U. 1994, nr 74, poz. 336).

27 ARM, 2963/5 KSPRM, pismo L-I-983/94 Ministra Spraw Wewnętrznych (w/z podsekretarz stanu Henryk Jasik) z dnia 12.04.1995 r., bp. [dokument nr 18 sprawy].

28 Ibidem.

29 Ibidem.

${ }^{30}$ Ibidem.

31 Ibidem. 
oraz organy partii politycznych, zwrócono uwagę na wymóg wprowadzania wykazu akt w porozumieniu z Naczelnym Dyrektorem. Podkreślono, że „ze względu na fakt, iż wykaz akt jest odzwierciedleniem metod i form pracy operacyjnej (prowadzonej w sposób tajny) brak jest podstawy do ingerencji Naczelnego Dyrektora w tej dziedzinie, chyba że Minister Spraw Wewnętrznych wyrazi na to zgodę"32. Podniesiono również kwestię zezwolenia Naczelnego Dyrektora na brakowanie dokumentacji niearchiwalnej, stwierdzając przy tym, że „powstaje problem ujawnienia tajemnicy państwowej i służbowej" ze względu na niejasny zakres uszczegółowienia spisu dokumentacji niearchiwalnej przeznaczonej do przekazania na makulaturę lub zniszczenie ${ }^{33}$.

Nie zyskał uznania w oczach MSW również projekt rozporządzenia Prezesa Rady Ministrów w sprawie zakresu i trybu merytorycznego nadzoru archiwalnego Naczelnego Dyrektora do Spraw Archiwalnych Rzeczypospolitej Polskiej nad działalnością państwowych archiwów bieżących. Najważniejszym zarzutem był zakres nadzoru Naczelnego Dyrektora (obejmujący gromadzenie, ewidencjonowanie, przechowywanie, opracowanie, zabezpieczanie i udostępnianie materiałów archiwalnych oraz dokumentacji niearchiwalnej, a także przekazywanie materiałów archiwalnych do państwowych archiwów historycznych, brakowanie dokumentacji niearchiwalnej oraz prowadzenie działalności informacyjnej), co miało oznaczać „głęboką ingerencję w pracę archiwów poprzez nadzór nad gromadzeniem, ewidencjonowaniem, opracowywaniem, zabezpieczaniem i udostępnianiem materiałów, natomiast pominięto całkowicie ochronę tajemnicy, co jest specyfiką archiwów służb specjalnych" ${ }^{\prime 3}$. Stwierdzono ponadto, iż uprawnienia Naczelnego Dyrektora do żądania przedłożenia do uzgodnienia lub wiadomości planów pracy państwowych archiwów bieżących, „szczególnie w przypadku Biura Ewidencji i Analiz UOP jest równoznaczne z planem pracy służb specjalnych, a więc może stwarzać zagrożenie dla interesu bezpieczeństwa państwa" ${ }^{35}$.

Ta, i tak skondensowana, analiza pisma MSW z 12 kwietnia 1995 r. pokazuje dobitnie skalę zarzutów do samego projektu ustawy, jak również do jej aktów wykonawczych, które to akty - nie biorąc pod uwagę specyfiki działalności zwłaszcza służb specjalnych i ich archiwów - bez żadnych kompromisów i wyjątków, próbowały narzucić rsw i jego archiwom swoiste „ubezwłasnowolnienie" w zakresie prowadzenia działalności archiwalnej. Nic zatem dziwnego, że uznano przedmiotowy projekt za nieuzgodniony z $\mathrm{MSW}^{36}$.

\footnotetext{
${ }^{32}$ Ibidem.

${ }^{33}$ Ibidem.

${ }^{34}$ Ibidem.

${ }^{35}$ Ibidem. W korespondencji pojawił się błąd: nie funkcjonowało wtedy Biuro Ewidencji i Analiz UOP, lecz Biuro Ewidencji i Archiwum UOP.

${ }^{36}$ Ibidem.
} 
W związku z tym, jak również z dużymi zastrzeżeniami do zapisów projektu ze strony Ministerstwa Finansów, Zakładu Ubezpieczeń Społecznych i Głównego Urzędu Statystycznego, w dniu 28 kwietnia 1995 r. zwołano kolejną konferencję uzgodnieniową w MEN ${ }^{37}$. Strony biorące udział w spotkaniu w dalszym ciągu podtrzymywały wzajemny rozdźwięk w zakresie brzmienia art. 51 projektu ustawy. MSW powtórzyło, że projekt ustawy stanowi kolizję ,z przepisami ustawy o urzędzie MSW oraz ustawy o ochronie tajemnicy państwowej i służbowej i jest daleko idącym ograniczeniem kompetencji Ministra Spraw Wewnętrznych w zakresie zarządzania zasobami archiwalnymi resortu" ${ }^{38}$. Ponadto podkreślono, iż „nie ma racjonalnego uzasadnienia dla rozszerzenia kręgu osób, którym są udostępniane materiały archiwalne, w większości opatrzone klauzulą tajności" ${ }^{39}$. W związku z tym MEN przedłożył dwa warianty brzmienia art. 51 - pierwszy był propozycją resortu edukacji narodowej, drugi MSW. Jak słusznie zauważono, „oba warianty są wobec siebie rozłączne i trzeba dokonać wyboru jednego z nich. W ocenie MEN, wariant II (tj. propozycja MSW) zachowuje istotę istniejących obecnie wyodrębnionych archiwów MSW, gdy tymczasem jedną z idei przewodnich projektu ustawy jest zniesienie archiwów wyodrębnionych" ${ }^{40}$.

Wobec nieusunięcia rozbieżności pomiędzy MEN a MSW, interwencję u przewodniczącego KSPRM Leszka Millera, podjął Naczelny Dyrektor, który w zakresie statusu archiwów MSW - podkreślił, że pozostają one „poza wszelką kontrolą archiwalną" ${ }^{41}$, co miało odbiegać od standardów europejskich, sygnalizowanych przez misję Międzynarodowej Rady Archiwów w Polsce w marcu 1995 r. Jak podkreślił, w pierwotnej wersji projektu ustawy, Centralne Archiwum MSW miało posiadać status państwowego archiwum bieżącego, wypełniającego jednocześnie zadania archiwum historycznego i jako takie miało podlegać Naczelnemu Dyrektorowi do Spraw Archiwalnych. Stwierdził dalej, że - wskutek braku akceptacji MSW dla takiego rozwiązania - „proponujemy, aby archiwa

${ }^{37}$ Ibidem, pismo KSPRM-10-13-95 podsekretarza stanu w Urzędzie Rady Ministrów (dalej: URM), sekretarza KSPRM Lecha Nikolskiego do Ministra Edukacji Narodowej Ryszarda Czarnego z 24.04.1995 r., bp. [dokument nr 39 sprawy] oraz pismo DP-0151-74/94/MJ Ministra Edukacji Narodowej (w zastępstwie podsekretarz stanu w MEN Kazimierz Przybysz) z 26.04.1995 r., bp. [dokument nr 40 sprawy].

${ }^{38}$ Ibidem, notatka dla przewodniczącego Komitetu Społeczno-Politycznego Rady Ministrów Pana Ministra Leszka Millera z 05.05.1995 r. (autor: W. Jakubas), bp.

${ }^{39}$ Ibidem.

40 Ibidem.

${ }^{41}$ AZ NDAP, 486/5 NDAP, WOiP, pismo WOU-0000-1/95 Naczelnego Dyrektora Archiwów Państwowych Jerzego Skowronka do przewodniczącego KSPRM Leszka Millera z 06.05.1995 r., s. 41-42. Dokument dostępny również w: ARM, 2963/5 KSPRM, pismo WOU-0000-1/95 Naczelnego Dyrektora Archiwów Państwowych Jerzego Skowronka do przewodniczącego KSPRM Leszka Millera z 06.05.1995 r. oraz notatka w związku z ostatnim posiedzeniem uzgodnieniowym projektu ustawy „Prawo archiwalne”, bp. [dokument nr 44 sprawy]. 
MSW i UOP wykonywały tylko zadania państwowego archiwum bieżącego"42, a tryb kontroli i nadzoru oraz zasady przekazywania materiałów archiwalnych do archiwów państwowych miało określać rozporządzenie premiera. Według Naczelnego Dyrektora miało to wprowadzić „,czynnik pozaresortowej kontroli i nadzoru nad archiwalną działalnością MSW" ${ }^{33}$.

Już kilka dni później, 9 maja 1995 r., nad projektem ustawy - Prawo archiwalne i jej aktami wykonawczymi debatował KSPRM pod przewodnictwem L. Millera. Podtrzymano na nim zastrzeżenia MSW do brzmienia art. 24 i 51 projektu ustawy, a sam KSPRM ,po dyskusji i próbie uzgodnienia rozbieżności:

- przyjął projekt co do zasady;

- w związku z podtrzymaniem zastrzeżeń nie rekomendował projektu Radzie Ministrów;

- zobowiązał wnioskodawcę do przeprowadzenia kolejnej tury uzgodnień i w porozumieniu z sekretarzem KSPRM;

- w przypadku usunięcia rozbieżności upoważnił wnioskodawcę do skierowania, w porozumieniu z sekretarzem Komitetu, projektu pod obrady Rady Ministrów albo z protokołem rozbieżności ponownie pod obrady Komitetu" 4 .

Dnia 25 maja odbyło się posiedzenie Komisji Uzgodnieniowej z upoważnienia KSPRM, w trakcie której przedstawiciele MSW zostali zobowiązani do przedstawienia w ciągu trzech tygodni projektu rozporządzenia Prezesa Rady Ministrów, określającego ,zasady merytorycznego nadzoru archiwalnego sprawowanego przez Naczelnego Dyrektora do Spraw Archiwalnych RP nad archiwami resortu spraw wewnętrznych" 45 .

Z kolei 6 czerwca, w dniu obrad Rady Archiwalnej, dr Grzegorz Jakubowski, dyrektor Centralnego Archiwum MSW, ,przekazał nieformalnie p. dr. Andrzejowi Biernatowi Zastępcy Naczelnego Dyrektora Archiwów Państwowych pisemną propozycję odnoszącą się do współpracy między Centralnym Archiwum MSW a Naczelnym Dyrektorem do Spraw Archiwalnych RP"46. Propozycja

${ }^{42}$ AZ NDAP, 486/5 NDAP, WOiP, pismo WOU-0000-1/95 Naczelnego Dyrektora Archiwów Państwowych Jerzego Skowronka do przewodniczącego KSPRM Leszka Millera z 06.05.1995 r., s. 41

${ }^{43}$ Ibidem.

${ }^{44}$ ARM, 2963/5 KSPRM, Protokół ustaleń Nr 6/95 z posiedzenia Komitetu Społeczno-Politycznego Rady Ministrów w dniu 9 maja 1995 r., bp.

${ }^{45}$ AZ NDAP, 486/5 NDAP, WOiP, pismo WOU-0000-1/95 Naczelnego Dyrektora Archiwów Państwowych Jerzego Skowronka do podsekretarza stanu w MEN, Kazimierza Przybysza z 14.06.1995 r., s. 45.

${ }^{46}$ Ibidem. Było to pierwsze posiedzenie Rady Archiwalnej kadencji 1995-1997. W jego trakcie zwrócono uwagę, że ,prace związane z nowym ustawodawstwem archiwalnym napotykają na trudności. Będą podejmowane rozmowy na ten temat i próby nowelizacji dotychczas obowiązujących przepisów”. Zob.: B. Woszczyński, Rada Archiwalna kadencji 1995-1997, „Archeion” 1998, t. 99, s. $339-340$. 
G. Jakubowskiego zakładała, iż Naczelny Dyrektor - w drodze porozumienia - miał otrzymywać zbiorcze dane roczne na temat wielkości zasobu archiwalnego rsw, stanu opracowania materiałów archiwalnych w archiwach resortu, udostępniania dokumentacji do celów pozasłużbowych oraz brakowania dokumentacji niearchiwalnej. Ponadto MSW miało przekazywać ,inwentarze (spisy) akt (jawnych i odtajnionych), przeznaczonych do udostępnienia"47. Ostatnim punktem propozycji było przekazywanie informacji o działalności wydawniczej CA MSW ${ }^{48}$.

Odpowiadając na propozycję MSW, Naczelny Dyrektor stwierdził, że „nie spełnia elementarnych wymogów merytorycznego nadzoru archiwalnego Naczelnego Dyrektora do Spraw Archiwalnych RP nad działalnością archiwów MSW"49. Jednocześnie zaproponował nadanie archiwom rsw „statusu archiwów bieżących spełniających jednocześnie zadania archiwów historycznych pod warunkiem sprawowania archiwalnego nadzoru merytorycznego nad tymi archiwami przez Naczelnego Dyrektora do Spraw Archiwalnych RP oraz pod warunkiem udostępniania zasobu historycznego tych archiwów na ogólnych zasadach obowiązujących w państwowych archiwach historycznych" 50 . Dodał przy tym, że jest skłonny „,zaproponować Ministrowi Spraw Wewnętrznych, aby bezpośrednią kontrolę wynikającą z merytorycznego nadzoru archiwalnego Naczelnego Dyrektora do Spraw Archiwalnych RP wykonywał pracownik państwowej administracji archiwalnej wybrany przez ministra spraw wewnętrznych spośród osób wskazanych przez Naczelnego Dyrektora do Spraw Archiwalnych RP, czyli mogłaby być to osoba, która oprócz posiadania archiwalnych kwalifikacji merytorycznych spełniałaby wymogi stawiane przez Ministra Spraw Wewnętrznych" $"$.

Była to duża zmiana stanowiska NDAP w odniesieniu do opinii zawartych w piśmie z 6 maja. Mimo kolejnych rozmów przeprowadzonych 14 czerwca w NDAP z przedstawicielami MSW i MEN, nie została ona przyjęta. Dnia 16 czerwca MSW poinformowało, że „nie udało się znaleźć rozwiązania kompromisowego dotyczącego zapisu art. 51 ust. $3^{\text {"'52 }}$. W zamian za to zaproponowało nową wersję jego brzmienia w postaci:

${ }^{47}$ ARM, 2963/5 KSPRM, dokument z odręcznym tytułem „Propozycja dyr. Jakubowskiego o. 6 VI 95", stanowiący załącznik do pisma WOU-0000-1/95 Naczelnego Dyrektora Archiwów Państwowych Jerzego Skowronka do podsekretarza stanu w MEN, Kazimierza Przybysza z 14.06.1995 r., bp.

48 Ibidem.

${ }^{49}$ AZ NDAP, 486/5 NDAP, WOiP, pismo WOU-0000-1/95 Naczelnego Dyrektora Archiwów Państwowych Jerzego Skowronka do podsekretarza stanu w MEN, Kazimierza Przybysza z 14.06.1995 r., s. 45.

50 Ibidem, s. 45.

51 Ibidem, s. 46.

${ }^{52}$ Ibidem, pismo CA-2122/95 Ministra Spraw Wewnętrznych (z up. Jerzy Zimowski) do podsekretarza stanu w URM, sekretarza KSPRM Lecha Nikolskiego z 16.04.1995 r., s. 49. 
„3. Archiwa resortu spraw wewnętrznych stają się z dniem wejścia w życie ustawy państwowymi archiwami bieżącymi, spełniającymi jednocześnie zadania archiwów historycznych. Uprawnienia Naczelnego Dyrektora w stosunku do archiwów resortu spraw wewnętrznych wykonuje Minister Spraw Wewnętrznych, poprzez Dyrektora Centralnego Archiwum MSW.

Zasady współpracy archiwów spraw wewnętrznych z państwową administracja archiwalną określi porozumienie Ministra Spraw Wewnętrznych z Naczelnym Dyrektorem" ${ }^{\prime 3}$.

W przedmiotowym porozumieniu miał się znaleźć dodatkowo zapis, że „przejmując, przechowując, opracowując, brakując i udostępniając akta resortu spraw wewnętrznych stosuje się zasady obowiązujące w państwowej administracji archiwalnej, opierając się na przepisach wydanych przez Naczelnego Dyrektora" ${ }^{54}$. Dodatkowo Naczelny Dyrektor miał otrzymywać z CA MSW informacje zawarte w propozycji G. Jakubowskiego z 6 czerw$\mathrm{ca}^{55}$.

Z kolei MEN 17 czerwca również poinformowało, że nie udało się osiągnąć porozumienia z MSW, stwierdzając przy tym, że ów resort nie przedstawił projektu rozporządzenia w sprawie nadzoru i kontroli nad jego archiwami, lecz jedynie kilkupunktową ,propozycję” współpracy z Naczelnym Dyrektorem do Spraw Archiwalnych RP oraz że MSW utrzymuje „sprzeciw wobec sprawowania nadzoru archiwalnego przez Naczelnego Dyrektora" ${ }^{56}$. Zaproponowano również ostateczne brzmienie art. $51 \mathrm{w}$ postaci:

„1. Archiwa państwowe wyodrębnione, istniejące $\mathrm{w}$ dniu wejścia $\mathrm{w}$ życie ustawy, stają się archiwami państwowymi bieżącymi, spełniającymi jednocześnie zadania archiwów historycznych w zakresie określonym w art. 28 ust. 2 pkt $1^{57} \mathrm{w}$ odniesieniu do materiałów historycznych, dotyczących danej instytucji, przechowywanych w dniu wejścia w życie ustawy oraz wytworzonych po tej dacie, z zastrzeżeniem ust. 2.

53 Ibidem.

54 Ibidem.

55 Ibidem, s. 50. Przedmiotowe pismo w oryginale w: ARM, 2963/5 KSPRM, bp. [dokument nr 49 sprawy].

${ }^{56}$ ARM, 2963/5 KSPRM, pismo DP-0151-74/94/MJ Ministra Edukacji Narodowej (w/z podsekretarz stanu w MEN Kazimierz Przybysz) do podsekretarza stanu w URM, sekretarza KSPRM Lecha Nikolskiego z 17.06.1995 r., bp. [dokument nr 50 sprawy].

57 ARM, 2963/5 KSPRM, art. 28 ust. 2 pkt 1 projektu ustawy - Prawo archiwalne przesłany za pismem DP-0151-74/94/MJ Ministra Edukacji Narodowej do dyrektora Sekretariatu KSPRM z dnia 27.03.1995 r., bp. [s. 9 projektu]: „Archiwum może spełniać jednocześnie zadania archiwum bieżącego i historycznego, jeżeli, będąc archiwum bieżącym: 1) przechowuje historyczne materiały dotyczące danej instytucji, przy czym w odniesieniu do państwowych archiwów bieżących następuje to wyłącznie na zasadach określonych w ustawie lub przepisach wydanych z upoważnienia ustawy". 
2. Centralne Archiwum Wojskowe staje się z dniem wejścia w życie ustawy centralnym państwowym archiwum historycznym. Uprawnienia Naczelnego Dyrektora określone w art. $31 \mathrm{w}$ stosunku do Centralnego Archiwum Wojskowego wykonuje Minister Obrony Narodowej w porozumieniu z Naczelnym Dyrektorem.

3. Merytoryczny nadzór archiwalny nad archiwami, o których mowa w ust. 1 i 2 sprawuje Naczelny Dyrektor. Zakres i tryb tego nadzoru określa w drodze rozporządzenia Prezes Rady Ministrów, po zasięgnięciu opinii Rady Archiwalnej.

4. Organy państwowe prowadzące archiwa, o których mowa w ust. 1 wydadzą w ciągu sześciu miesięcy od dnia wejścia w życie ustawy, w porozumieniu z Naczelnym Dyrektorem, regulaminy tych archiwów, uwzględniając przepisy ustawy"s8.

W dalszej korespondencji uzupełniono, iż treść art. 51 ust. 1 i 3 ,zakłada jednolity status dla wszystkich obecnie działających archiwów wyodrębnionych - w tym także archiwów resortu spraw wewnętrznych" ${ }^{59}$. Skonstatowano jednocześnie, że „propozycja MSW wyłącza archiwa tego resortu spod merytorycznego nadzoru i kontroli Naczelnego Dyrektora. Mają one nadal być nadzorowane i kontrolowane przez Ministra Spraw Wewnętrznych, czyli ich status nie uległby faktycznej zmianie. Archiwa te jedynie współpracowałyby z państwową administracja archiwalną na zasadach określonych nie w samej ustawie, czy w aktach wykonawczych do niej, lecz w porozumieniu Ministra Spraw Wewnętrznych z Naczelnym Dyrektorem"60.

Powyższe stanowiska zreferowano 20 czerwca w KSPRM, odnotowując, że „obie strony twierdzą, że w poszukiwaniu kompromisowego rozwiązania okazały maksimum dobrej woli, ale dalsze zbliżenie stanowisk nie jest możliwe" ${ }^{" 1}$. Doprowadziło to do wniosku, że jeżeli MEN i MSW nie osiągną porozumienia $\mathrm{w}$ trakcie kolejnej tury uzgodnień i nie zostaną zgłoszone nowe uwagi do projektu, to propozycją wyjścia z tej sytuacji będzie przedstawienie projektu Radzie Ministrów z wnioskiem o rozstrzygnięcie sporu ${ }^{62}$. W efekcie - w trakcie kolejnego posiedzenia KSPRM w dniu 21 czerwca - zawarto konstatację, iż „po dyskusji, wobec nie uzgodnienia stanowisk MEN i MSW w sprawie treści art. 51 projektu ustawy Komitet Społeczno-Polityczny Rady Ministrów rekomenduje

\footnotetext{
${ }^{58}$ ARM, 2963/5 KSPRM, pismo DP-0151-74/94/MJ Ministra Edukacji Narodowej (w/z podsekretarz stanu w MEN Kazimierz Przybysz) do podsekretarza stanu w URM, sekretarza KSPRM Lecha Nikolskiego z 17.06.1995 r., bp. [dokument nr 50 sprawy].

${ }^{59}$ Ibidem, pismo DP-0151-74/94/MJ wicedyrektora Departamentu Prawnego MEN Joanny Rozwadowskiej-Skrzeczyńskiej do Sekretariatu KSPRM z 19.06.1995 r., bp. [dokument nr 51 sprawy].

${ }^{60}$ Ibidem.

${ }^{61}$ Ibidem, Notatka dla Pana Ministra Leszka Millera, przewodniczącego Komitetu Społeczno-Politycznego Rady Ministrów z 20.06.1995 r., bp. [dokument nr 52 sprawy].

${ }^{62}$ Ibidem.
} 
Radzie Ministrów projekt z rozbieżnością dotyczącą merytorycznego nadzoru archiwalnego nad archiwami MSW"63.

Odzwierciedleniem tych rozbieżności jest projekt ustawy z tego samego dnia, 21 czerwca, w którym zawarto oba warianty brzmienia art. 51. Pierwszy wariant był tożsamy z czteropunktową propozycją MEN z 17 czerwca. Z kolei wariant drugi to pięciopunktowa propozycja MSW, gdzie ust. 3 był literalnym powtórzeniem zapisów z pisma wiceministra Zimowskiego z 16 czerwca, podczas gdy dwa dotychczasowe ustępy uległy odpowiedniemu przesunięciu do ustępów nr 4 i $5^{64}$.

Co ciekawe, posiedzenie KSPRM z 21 czerwca i projekt ustawy z tego dnia okazały się być katalizatorem buntu archiwów wyodrębnionych względem propozycji MEN i NDAP. Argumenty MSW podzielił bowiem Minister Obrony Narodowej, który zaproponował nowy ustęp w brzmieniu:

„Archiwa resortu spraw wewnętrznych i obrony narodowej, z wyjątkiem Centralnego Archiwum Wojskowego, o którym mowa w ust. 2, stają się z dniem wejścia w życie ustawy państwowymi archiwami bieżącymi, spełniającymi jednocześnie zadania archiwów historycznych. Uprawnienia Naczelnego Dyrektora w stosunku do tych archiwów wykonują odpowiednio Ministrowie Spraw Wewnętrznych i Obrony Narodowej" 65 .

Do MSW i MON dołączyło również MSZ, które pismem z 11 lipca powiadomiło, iż „konsekwentnie opowiada się za utrzymaniem wyodrębnionych archiwów” oraz że brzmienie art. 51 ,jest nie do przyjęcia"66. Poparło jednocześnie wariant nr II projektu „uznając, że archiwa wyodrębnione powinny posiadać taki sam status jak Centralne Archiwum Wojskowe (art. 51 ust. 2)" i w związku $\mathrm{z}$ tym wniosło, aby w artykule 51 ust. 3, po słowach „Archiwa resortu spraw wewnętrznych”, dopisać wyrażenie „i spraw zagranicznych”, a dalej dostosować zapis brzmienia artykułu do nowej treści ${ }^{67}$.

${ }^{63}$ Ibidem, Protokół ustaleń Nr 13/95 z posiedzenia Komitetu Społeczno-Politycznego Rady Ministrów w dniu 21 czerwca 1995 r., bp. [dokument nr 63 sprawy].

${ }^{64}$ AZ NDAP, 486/5 NDAP, WOiP, Projekt ustawy - Prawo archiwalne z dnia 21.06.1995 r., s. $67-$ 68. W wariancie II (MSW) uzupełniono dodatkowo zapis art. 51 ust. 1 do postaci: „Archiwa państwowe wyodrębnione, istniejące w dniu wejścia w życie ustawy, stają się archiwami państwowymi bieżącymi, spełniającymi jednocześnie zadania archiwów historycznych w zakresie określonym w art. 28 ust. 2 pkt $1 \mathrm{w}$ odniesieniu do materiałów historycznych, dotyczących danej instytucji, przechowywanych w dniu wejścia w życie ustawy oraz wytworzonych po tej dacie, z zastrzeżeniem ust. 2 i 3".

${ }^{65}$ Ibidem, pismo nr 207/4/95/DP Ministra Obrony Narodowej Zbigniewa Okońskiego do sekretarza stanu i sekretarza Rady Ministrów Grzegorza Rydlewskiego z 29.06.1995 r., s. 83-86.

${ }^{66}$ Ibidem, pismo DPT II 021-157-94 dyrektora generalnego w MSZ Janusza Stańczyka do podsekretarza stanu w MEN, Kazimierza Przybysza z 11.07.1995 r., s. 90.

${ }^{67}$ Ibidem, s. 92. Należy dodać, iż w dniach 10 i 11 VII 1995 r. w URM miało się odbyć posiedzenie Komisji Prawniczej, organizowane przez Departament Prawny URM, dotyczące rozpatrzenia projektu ustawy - Prawo archiwalne oraz projektów jej aktów wykonawczych. Zob.: ibidem, pismo nr PR 10/136/94 dyrektora Departamentu Prawnego URM Aleksandra Proksy do NDAP z 28 VI 1995 r., s. 52. Nie dotarłem do materiałów z posiedzenia wymienionej komisji 
MSZ argumentował przy tym, że archiwum tego resortu, stanowiąc komórkę organizacyjną ministerstwa równą departamentowi, pełni szersze funkcje (prowadzi nadzór kancelaryjny w placówkach dyplomatycznych i konsularnych poza graniami kraju, kontroluje przestrzeganie tajemnicy państwowej w całym resorcie). Podkreślano, iż archiwum MSZ odpowiada za informacyjne zabezpieczenie centrali resortu (publikacje zbioru umów międzynarodowych oraz dotyczących stosunków dyplomatycznych z innymi państwami, udzielanie informacji) a, przede wszystkim, przechowuje ważne i podlegające szczególnej ochronie dokumenty. Wskazywano, że archiwum MSZ ,stanowi bardzo ważne ogniwo, w nie mającym odpowiednika w kraju systemie obiegu dokumentów i łączności”"68. Z kolei $-\mathrm{z}$ konieczności posiadania specjalistycznej wiedzy $-\mathrm{w}$ archiwum MSZ należy zatrudniać pracowników służby dyplomatyczno-konsularnej, którzy mieliby taki sam status jak pozostali pracownicy centrali resortu spraw zagranicznych ${ }^{69}$.

Po wpływie pisma z MSZ, swojego zaskoczenia nie krył Naczelny Dyrektor, który odnotował 12 lipca ,dlaczego tak późna i zbiorowa reakcja”" ${ }^{\text {"Po }}$. Podkreślając zalecenia Międzynarodowej Rady Archiwów wskazywał, że „archiwa centralne gromadzą całość dokumentacji centralnych urzędów państwowych (w Wielkiej Brytanii Foreign Office przekazuje pod ochronę Archiwum Narodowemu dokumenty sprzed 3-4 lat! Oczywiście bez prawa udostępniania ich publiczności przed określonym terminem)" "71. Wskazywał równocześnie, że „,nadzór merytoryczny wyspecjalizowanych służb archiwalnych (inspektorów) jest uznawany za fundamentalny element kontroli i demokratyzacji archiwów"72.

Stanowisko archiwów wyodrębnionych spotkało się następnie z kontrreakcją Naczelnego Dyrektora, który 17 lipca osobiście spotkał się z Ministrem Spraw Wewnętrznych, Andrzejem Milczanowskim. W trakcie spotkania przekazał mu

ale to, że się odbyło, jest faktem bezspornym, ponieważ wspominał o niej Naczelny Dyrektor w piśmie do Ministra Spraw Zagranicznych z 20 VII 1995 r. W jej trakcie przedstawiciel MSZ powrócił do lutowych zastrzeżeń swojego resortu do zapisów projektu ustawy. Zob.: ibidem, pismo WOU-0000-1/95 Naczelnego Dyrektora Archiwów Państwowych Jerzego Skowronka do Ministra Spraw Zagranicznych Władysława Bartoszewskiego z 20.07.1995 r., s. 113. Ponadto Naczelny Dyrektor wspomniał o obradach Komisji Prawniczej w piśmie do podsekretarza stanu w MEN z 20 lipca 1995 r. W jej trakcie miały uwypuklić się rozbieżności „burzące dotychczasowe uzgodnienia". Zob.: ibidem, Pismo WOU-0000-1/95 Naczelnego Dyrektora Archiwów Państwowych Jerzego Skowronka do podsekretarza stanu w MEN, Kazimierza Przybysza z 20 VII 1995 r., s. 110.

${ }^{68}$ Ibidem, pismo DPT II 021-157-94 dyrektora generalnego w MSZ Janusza Stańczyka do podsekretarza stanu w MEN, Kazimierza Przybysza z 11.07.1995 r., s. 91.

${ }^{69}$ Ibidem.

${ }^{70}$ Ibidem, dekretacja odręczna Naczelnego Dyrektora Archiwów Państwowych na faksie pisma DPT II 021-157-94 dyrektora generalnego w MSZ Janusza Stańczyka do podsekretarza stanu w MEN, Kazimierza Przybysza z 11.07.1995 r., s. 98.

${ }^{71}$ Ibidem.

72 Ibidem, s. 99. 
również swoje pismo, w którym - po przedstawieniu całej wcześniejszej argumentacji, formułowanej przez NDAP od 6 maja - zwracał uwagę, iż „będzie można, stosując specjalne przepisy prawa, przyjąc takie rozwiązania organizacyjno-personalne, które pozwolą na przestrzeganie zapisów zawartych w cytowanych przez Pana Ministra ustawach o urzędzie Ministra Spraw Wewnętrznych, o Urzędzie Ochrony Państwa oraz o ochronie tajemnicy państwowej i służbowej"?

Następnie, 20 lipca, Naczelny Dyrektor wystosował korespondencję do Ministra Spraw Zagranicznych, Władysława Bartoszewskiego, w której stwierdził, że „opowiadanie się za utrzymaniem archiwów wyodrębnionych jest podtrzymywaniem starego systemu, który nie odpowiada warunkom demokratycznego Państwa"74. Próbował przy tym tłumaczyć, że wnioskowany w zapisach projektu ustawy nadzór merytoryczny ,sprowadzałby się do oceny zgodności działania na polu archiwalnym MSZ i podległych mu jednostek z obowiązującymi przepisami archiwalnymi wraz z możliwością ingerencji poprzez właściwego ministra w sytuacji stwierdzonych nieprawidłowości" ${ }^{75}$. Zakres nadzoru i kontroli, które miały być określone w rozporządzeniu premiera, planowano przygotować $\mathrm{w}$ trybie uzgodnień międzyresortowych, co dałoby możliwość wypowiedzenia się MSZ. Naczelny Dyrektor stwierdzał, że ustawa daje Archiwum MSZ możliwość „długotrwałego przechowywania wytworzonych przez macierzystą instytucję materiałów archiwalnych ze wszystkimi wynikającymi z tego konsekwencjami np. w zakresie udostępniania materiałów"76. Naczelny Dyrektor podkreślał także, że projekt ustawy nakłada na ministra obowiązek zatrudniania osób z odpowiednimi kwalifikacjami, ale nie oznacza to zatrudniania tych osób na innych warunkach niż przyjęte w MSZ ${ }^{77}$.

Jeszcze tego samego dnia krytyka oporu trzech resortów (MSW, MON, MSZ) względem zapisów projektu ustawy znalazła swoje odzwierciedlenie w korespondencji Naczelnego Dyrektora do wiceministra edukacji narodowej, w któ-

${ }^{73}$ Ibidem, kopia pisma WOU-0000-1/95 Naczelnego Dyrektora Archiwów Państwowych Jerzego Skowronka do Ministra Spraw Wewnętrznych Andrzeja Milczanowskiego z 17.07.1995 r., s. 102 103. Na kopii pisma odręczny zapisek o treści: „Pismo przekazałem w bezpośredniej rozmowie z Ministrem A. Milczanowskim w dn. 17.07".

${ }^{74}$ Ibidem, pismo WOU-0000-1/95 Naczelnego Dyrektora Archiwów Państwowych Jerzego Skowronka do Ministra Spraw Zagranicznych Władysława Bartoszewskiego z 20.07.1995 r., s. 114.

${ }^{75}$ Ibidem, s. 113-114.

${ }^{76}$ Ibidem, s. 114.

${ }^{77}$ Ibidem. W odpowiedzi MSZ stwierdziło, iż opowiedziało się za wariantem II projektu oraz dopisaniem w art. 51 ust. 3 - po archiwach MSW - również resortu spraw zagranicznych. MSZ podkreśliło, iż tym sposobem „uzyskałoby ustawowe potwierdzenie, że spełniające różnorakie funkcje Archiwum MSZ będzie państwowym archiwum bieżącym spełniającym jednocześnie zadania archiwów historycznych. Z treści Pańskiego listu wnoszę, że taki charakter Archiwum MSZ jest zgodny również ze stanowiskiem Pana Dyrektora". Ibidem, pismo DPT II 021-157-94 dyrektora generalnego w MSZ Janusza Stańczyka do Naczelnego Dyrektora Archiwów Państwowych Jerzego Skowronka z 28.07.1995 r., s. 134 . 
rej „zmasowane wystąpienia trzech ministerstw” ocenił jako budzące niepokój i zdziwienie, stwierdzając iż wcześniej istniała tylko jedna kontrowersja, wynikająca z postawy MSW. Stwierdzał, że dotychczasowa działalność archiwalna wymienionych ministerstw w zakresie gromadzenia, przechowywania i ewidencjonowania dokumentacji ,znajdowała się poza jakąkolwiek kontrolą i nadzorem merytorycznym"78.

Dalej przywołał opinię przedstawicieli Międzynarodowej Rady Archiwalnej z 12 kwietnia 1995 r., którzy stwierdzili, że ,jest zadziwiające z punktu widzenia technicznego, że wszystkie archiwa stworzone przez organy Rządu Polskiego nie podlegają bezpośrednio kontroli Naczelnego Dyrektora Archiwów Państwowych" "79. W związku z zaleceniem MRA, w projekcie ustawy proponowano zbudowanie jednolitego systemu zarządzania archiwami państwowymi, w którym Naczelny Dyrektor do Spraw Archiwalnych RP sprawowałby nadzór merytoryczny nad działalnością archiwalną wszystkich organów państwowych „wraz z możliwością ingerencji poprzez właściwego ministra w sytuacji stwierdzonych nieprawidłowości”"80.

Naczelny Dyrektor postulował wprowadzenie elementu ,pozaresortowego nadzoru wyspecjalizowanych służb archiwalnych nad wytwarzanymi i przechowywanymi wieczyście materiałami archiwalnymi" ${ }^{81} \mathrm{w}$ formie rozporządzenia premiera określającego zakres tego nadzoru i tryb przeprowadzania kontroli. Miało to dotyczyć - co stanowczo podkreślał Naczelny Dyrektor - również służb specjalnych.

W korespondencji zaznaczono, że archiwa MSW i MSZ będą państwowymi archiwami bieżącymi, spełniającymi również funkcje archiwów historycznych, co miało dać im prawo do długotrwałego przechowywania materiałów archiwalnych. Zaznaczono jednak szczególną odrębność CAW, które jako „osobna placówka archiwalna" posiada szczególny status, inny niż archiwa MSW i MSZ, które stanowią wewnętrzne jednostki organizacyjne instytucji, w których funkcjonują. Samo CAW miało posiadać status centralnego archiwum państwowego historycznego, a uprawnienia Naczelnego Dyrektora w jego przypadku miał wykonywać Minister Obrony Narodowej (choć w porozumieniu z tym pierw(szym) $)^{82}$.

Według Naczelnego Dyrektora, „takie rozwiązanie ustawowe sankcjonujące istnienie niektórych archiwów resortowych funkcjonujących na specjalnych prawach, a zwłaszcza mających możliwość gromadzenia zasobu historycznego, nie jest zgodne ze standardami Międzynarodowej Rady Archiwów lecz ostatecz-

78 Ibidem, pismo WOU-0000-1/95 Naczelnego Dyrektora Archiwów Państwowych Jerzego Skowronka do podsekretarza stanu w MEN, Kazimierza Przybysza z 20 VII 1995 r., s. 110.

79 Ibidem, s. 111.

80 Ibidem.

81 Ibidem.

82 Ibidem. 
ne przyjęcie takich zapisów przez Naczelną Dyrekcję Archiwów Państwowych i środowisko archiwistów było wyrazem postawy kompromisowej" ${ }^{83}$. Do tego proponował ,specjalne rozwiązania organizacyjno-personalne” w zakresie kontroli i nadzoru nad archiwami MSW i MON ze względu na charakter dokumentacji zawierającej tajemnicę państwową i służbową ${ }^{84}$.

W ocenie Naczelnego Dyrektora miała to być propozycja kompromisowa, odrzucenie której powodowałoby uznanie archiwów wyodrębnionych tylko za archiwa bieżące, zobowiązane do systematycznego przekazywania materiałów archiwalnych do archiwów historycznych. W odrębnym rozporządzeniu Rady Ministrów miałyby być określone dla tych archiwów zasady nadzoru, kontroli i okresy, w jakich powinny one przekazywać materiały historyczne ${ }^{85}$.

Kończąc, Naczelny Dyrektor poszedł jeszcze dalej w podsumowywaniu toczącego się sporu, niż w piśmie do MSZ, w którym domaganie się utrzymania archiwów wyodrębnionych uznał za podtrzymywanie starego systemu, nieodpowiadającego warunkom państwa demokratycznego. Stwierdził wręcz, że propozycje trzech wyżej wymienionych resortów „to nawet regres w stosunku do stanu jaki określała ustawa o narodowym zasobie archiwalnym i archiwach z 1983 r." $" 86$.

Jakby tych emocji było mało, tego samego dnia do NDAP wpłynęła korespondencja z Głównej Komisji Badania Zbrodni przeciwko Narodowi Polskiemu - Instytutu Pamięci Narodowej (dalej: GKBZpNP-IPN), w której jej dyrektor generalny postulował nadanie archiwum GKBZpNP-IPN takiego samego statusu, jaki postulowało dla siebie MSW. Miało to przybrać formę niniejszego zapisu art. 51:

„1. Archiwum Głównej Komisji Badania Zbrodni przeciwko Narodowi Polskiemu - Instytutu Pamięci Narodowej staje się z dniem wejścia w życie ustawy państwowym archiwum bieżącym, spełniającym jednocześnie zadania archiwum historycznego. Uprawnienia Naczelnego Dyrektora w stosunku do Archiwum Komisji wykonuje Minister Sprawiedliwości - Przewodniczący Głównej Komisji, poprzez Dyrektora Generalnego Komisji.

2. Zasady współpracy Archiwum Komisji z państwową administracją archiwalną określi porozumienie Ministra Sprawiedliwości - Przewodniczącego Głównej Komisji z Naczelnym Dyrektorem" ${ }^{\text {" } 7}$.

\footnotetext{
${ }^{83}$ Ibidem.

${ }^{84}$ Ibidem.

${ }^{85}$ Ibidem.

${ }^{86}$ Ibidem, s. 112.

${ }^{87}$ Ibidem, pismo WO/O/070/013/95 dyrektora generalnego GKBZpNP-IPN Ryszarda Walczaka do Naczelnego Dyrektora Archiwów Państwowych Jerzego Skowronka z 20.07.1995 r., s. 115. Ibidem, Uwagi dyrektora generalnego GKBZpNP-IPN do projektu ustawy "Prawo archiwalne" (z 21 czerwca 1995 r.), s. 104-108, zwł. s. 105.
} 
Przeciw takiemu specjalnemu statusowi archiwum GKBZpNP-IPN oponował Naczelny Dyrektor, który zauważył, iż proponowane brzmienie art. 51 odnosi się do dotychczasowych archiwów wyodrębnionych, tj. MSW, MON, MSZ, Kancelarii Prezydenta, Sejmu i Senatu. Uznał, że nie ma racjonalnego uzasadnienia dla pozbawienia Naczelnego Dyrektora do Spraw Archiwalnych RP prawa nadzoru i kontroli nad archiwum Głównej Komisji, które dotychczas funkcjonowało jako archiwum zakładowe z powierzonym zasobem archiwalnym. Podkreślając integralność archiwum GKBZpNP-IPN z resortem sprawiedliwości, wskazano, że „zrealizowanie postulatów Głównej Komisji w konsekwencji prowadziłoby do trwałego rozproszenia i dezintegracji zespołów archiwalnych, co przeczy fundamentalnym zasadom archiwalnym, przyjętym we wszystkich krajach”. Wskazywał przy tym, ,że w przeciwieństwie np. do archiwów MON, MSZ i MSW, Główna Komisja nie przechowuje dokumentacji związanej z działalnością służb specjalnych, bezpieczeństwem i ochroną Państwa"88.

Dnia 25 lipca 1995 r. Naczelny Dyrektor spotkał się Ministrem Obrony Narodowej Zbigniewem Okońskim, któremu przekazał swoją korespondencję dotyczącą uwag wyrażonych przez MON 29 czerwca. Oprócz przedstawienia wszystkich dotychczas wyrażonych argumentów uzasadniających wprowadzenie nowego prawa archiwalnego, Naczelny Dyrektor wskazał, że w projekcie ustawy CAW znalazło się w grupie państwowych archiwów historycznych, jako podlegające Ministrowi Obrony Narodowej. Miało to oznaczać, że „CAW jest samodzielną jednostką organizacyjną gromadzącą wieczyście materiały archiwalne” i stawało się „częścią państwowej administracji archiwalnej, a jego dyrektor organem państwowej administracji archiwalnej, który zyskuje odpowiednie uprawnienia m.in. do kontroli obowiązków jakie ciążą na właścicielu lub posiadaczu materiałów archiwalnych"89. Uznał jednocześnie propozycję dotyczącą brzmienia art. 51 za niezrozumiałą, odbierającą uprawnienia $\mathrm{CAW}^{90}$.

Wbrew dobremu nastrojowi spotkania, MON podtrzymał swoje opozycyjne stanowisko, proponując nową wersję zapisu dla art. 51 ust. $2 \mathrm{w}$ postaci:

„2. Centralne Archiwum Wojskowe staje się z dniem wejścia w życie ustawy centralnym państwowym archiwum historycznym. Uprawnienia Naczelnego Dyrektora określone w art. $31 \mathrm{w}$ stosunku do Centralnego Archiwum Wojskowego i w art. $33 \mathrm{w}$ stosunku do archiwów bieżących resortu obrony naro-

88 Ibidem.

${ }^{89}$ Ibidem, pismo WOU-0000-1/95 Naczelnego Dyrektora Archiwów Państwowych Jerzego Skowronka do Ministra Obrony Narodowej Zbigniewa Okońskiego z 25.07.1995 r., s. 130.

90 Ibidem, s. 130. Na piśmie odręczny zapisek o treści: „Pismo zostało przekazane w bezpośredniej rozmowie w dniu 25 lipca o godz. 9.37. Zostało przyjęte pozytywnie. Jerzy Skowronek. 25.07.95”, ibidem, s. 128. W nawiązaniu do spotkania Naczelnego Dyrektora z Ministrem Obrony Narodowej zastępca Naczelnego Dyrektora A. Biernat przesłał do zastępcy dyrektora Departamentu Prawnego MON aktualny projekt ustawy oraz projekty czterech aktów wykonawczych. Zob.: ibidem, pismo WOU-00001/95 zastępcy Naczelnego Dyrektora Archiwów Państwowych Andrzeja Biernata do zastępcy dyrektora Departamentu Prawnego MON płk. Zbigniewa Śpiewaka z 28.07.1995 r., s. 133. 
dowej, spełniających jednocześnie zadania archiwów historycznych, przysługują Ministrowi Obrony Narodowej, który je wykonuje w porozumieniu z Naczelnym Dyrektorem. Szczegółowe zasady wykonywania tych uprawnień określa porozumienie Ministra Obrony Narodowej z Naczelnym Dyrektorem"91.

W opinii MON była to propozycja kompromisowa, ponieważ „nie występuje w niej jednostronne ,zawłaszczenie” uprawnień jednego organu na rzecz drugiego" oraz ,wyklucza [ona] samodzielne działanie jakiegokolwiek podmiotu"

Należy podkreślić, iż pod koniec lipca 1995 r. dochodzi do zmiany redakcyjnej w projekcie ustawy poprzez wprowadzenie dodatkowego artykułu dotyczącego kategorii pracowników zatrudnianych w archiwach. Spowodowało to przesunięcie numeracji zapisów projektu, a uprzedni art. 51 został oznaczony jako art. $52^{93}$. MEN - przy okazji przesyłania zmodyfikowanego projektu ustawy do URM - zauważyło, iż brzmienie art. 52 ,zachowałoby istotę obecnie istniejących wyodrębnionych archiwów resortowych, zmieniając jedynie ich nazwę" Ostatecznie zatem projekt ustawy - Prawo archiwalne, po wpływie do URM na początku sierpnia 1995 r., posiadał dwa warianty zapisu art. 52, odnoszącego się do dotychczas funkcjonujących państwowych archiwów wyodrębnionych. Wariant I, proponowany przez MEN i NDAP, wyglądał następująco:

„1. Archiwa państwowe wyodrębnione, istniejące w dniu wejścia w życie ustawy, stają się archiwami państwowymi bieżącymi, spełniającymi jednocześnie zadania archiwów historycznych $\mathrm{w}$ zakresie określonym w art. 28 ust. 2 pkt $1 \mathrm{w}$ odniesieniu do materiałów historycznych, dotyczących danej instytucji, przechowywanych w dniu wejścia w życie ustawy oraz wytworzonych po tej dacie, $\mathrm{z}$ zastrzeżeniem ust. 2.

2. Centralne Archiwum Wojskowe staje się z dniem wejścia w życie ustawy centralnym państwowym archiwum historycznym. Uprawnienia Naczelnego Dyrektora określone w art. $31 \mathrm{w}$ stosunku do Centralnego Archiwum Wojskowego wykonuje Minister Obrony Narodowej w porozumieniu z Naczelnym Dyrektorem.

91 Ibidem, pismo nr 207/4/95 zastępcy dyrektora Departamentu Prawnego MON płk. Zbigniewa Śpiewaka do zastępcy Naczelnego Dyrektora Archiwów Państwowych Andrzeja Biernata z sierpnia 1995 r. [brak daty dziennej, wpływ do NDAP w dn. 24.08.1995 r.], s. 138.

92 Ibidem, s. 138.

93 ARM, 2880/78 URM, Sekretariat Rady Ministrów, pismo DP-0151-74/94/MJ Ministra Edukacji Narodowej (w/z sekretarz stanu w MEN Stefan J. Pastuszka) do sekretarza stanu w URM i sekretarza Rady Ministrów Grzegorza Rydlewskiego z 28.07.1995 r., bp. [dokument nr 1 sprawy]. Do pisma załączono zmieniony projekt ustawy - Prawo archiwalne oraz cztery projekty aktów wykonawczych. Co ciekawe, MON jeszcze w sierpniu 1995 r. bazuje na numeracji jako art. 51, a nie na zmienionej już w lipcu numeracji jako art. 52 .

94 Ibidem, s. 2 pisma DP-0151-74/94/MJ Ministra Edukacji Narodowej (w/z sekretarz stanu w MEN Stefan J. Pastuszka) do sekretarza Stanu w URM i sekretarza Rady Ministrów Grzegorza Rydlewskiego z 28.07.1995 r., bp. [dokument nr 1 sprawy] 
3. Merytoryczny nadzór archiwalny nad archiwami, o których mowa w ust. 1 i 2 sprawuje Naczelny Dyrektor. Zakres i tryb tego nadzoru określa w drodze rozporządzenia Prezes Rady Ministrów, po zasięgnięciu opinii Rady Archiwalnej.

4. Organy państwowe prowadzące archiwa, o których mowa w ust. 1 wydadzą w ciągu sześciu miesięcy od dnia wejścia w życie ustawy, w porozumieniu z Naczelnym Dyrektorem, regulaminy tych archiwów, uwzględniające przepisy ustawy"95.

Z kolei wariant II sprowadzał się do bardziej rozbudowanej postaci (propozycja MSW):

„1. Archiwa państwowe wyodrębnione, istniejące w dniu wejścia w życie ustawy, stają się archiwami państwowymi bieżącymi, spełniającymi jednocześnie zadania archiwów historycznych w zakresie określonym w art. 28 ust. 2 pkt $1 \mathrm{w}$ odniesieniu do materiałów historycznych, dotyczących danej instytucji, przechowywanych w dniu wejścia w życie ustawy oraz wytworzonych po tej dacie, z zastrzeżeniem ust. 2 i 3.

2. Centralne Archiwum Wojskowe staje się z dniem wejścia w życie ustawy centralnym państwowym archiwum historycznym. Uprawnienia Naczelnego Dyrektora określone w art. $31 \mathrm{w}$ stosunku do Centralnego Archiwum Wojskowego wykonuje Minister Obrony Narodowej w porozumieniu z Naczelnym Dyrektorem.

3. Archiwa resortu spraw wewnętrznych stają się z dniem wejścia w życie ustawy państwowymi archiwami bieżącymi, spełniającymi jednocześnie zadania archiwów historycznych. Uprawnienia Naczelnego Dyrektora w stosunku do archiwów resortu spraw wewnętrznych wykonuje Minister Spraw Wewnętrznych, poprzez dyrektora Centralnego Archiwum MSW.

Zasady współpracy archiwów spraw wewnętrznych z państwową administracja archiwalną określi porozumienie Ministra Spraw Wewnętrznych z Naczelnym Dyrektorem.

4. Merytoryczny nadzór archiwalny nad archiwami, o których mowa w ust. 1 i 2 sprawuje Naczelny Dyrektor. Zakres i tryb tego nadzoru określa w drodze rozporządzenia Prezes Rady Ministrów, po zasięgnięciu opinii Rady Archiwalnej.

5. Organy państwowe prowadzące archiwa, o których mowa w ust. 1 wydadzą w ciągu sześciu miesięcy od dnia wejścia w życie ustawy, w porozumieniu z Naczelnym Dyrektorem, regulaminy tych archiwów, uwzględniające przepisy ustawy"96.

${ }^{95}$ Ibidem, s. 16 projektu ustawy - Prawo archiwalne, przesłanego z pismem DP-0151-74/94/MJ Ministra Edukacji Narodowej (w/z sekretarz stanu w MEN Stefan J. Pastuszka) do sekretarza stanu w URM i sekretarza Rady Ministrów Grzegorza Rydlewskiego z 28.07.1995 r., bp. [dokument nr 1 sprawy].

${ }^{96}$ Ibidem, s. 16-17. 
Przy tego rodzaju określonych wariantach zapisu art. 52, projekt ustawy Prawo archiwalne stał się przedmiotem dyskusji na posiedzeniu Rady Ministrów w dniu 22 sierpnia 1995 r. W jego trakcie L. Miller, przewodniczący KSPRM, podkreślił, iż dla zapisu art. 52 ,nie udało się usunąć rozbieżności na skutek nieustępliwości stron". Z kolei wiceminister Jerzy Zimowski, jako przedstawiciel MSW podkreślił, iż dotychczas archiwa resortu spraw wewnętrznych były archiwami wydzielonymi, nad którymi nadzór sprawował minister spraw wewnętrznych. Podkreślał również „tajny charakter przechowywanych informacji”, które są nieweryfikowalne, a związane przede wszystkim ze sprawami bezpieczeństwa państwa. Stwierdził ponadto, że „funkcje Naczelnego Dyrektora do Spraw Archiwalnych w stosunku do archiwów resortu powinien wykonywać minister poprzez dyrektora Centralnego Archiwum MSW"97.

Ciekawe stanowisko zajął wiceminister spraw zagranicznych Robert Mroziewicz, który - zaznaczając, że kontrowersja w zakresie brzmienia art. 52 dotyczy jeszcze dwóch innych resortów - stwierdził, że „walczą w nim dwie dusze urzędnika i obywatela a równocześnie z wykształcenia historyka. Jako urzędnik chciałby utrzymać dotychczasowy charakter archiwum swojego resortu i na tym stanowisku stoją inni urzędnicy ministerstwa. Jako obywatel wypowiada się za jego - w miarę możliwości - otwartością a przede wszystkim za możliwością pozaresortowego nadzoru nad sposobami ewidencji, przechowywania i brakowania dokumentacji”. Po wezwaniu premiera Józefa Oleksego ostatecznie opowiedział się za wariantem pierwszym brzmienia art. 52, przychylając się tym samym do stanowiska MEN i NDAP ${ }^{98}$.

Niemniej dyskusja na posiedzeniu Rady Ministrów nie rozstrzygnęła ostatecznie kształtu projektu ustawy ponieważ przedstawiciel Ministerstwa Finansów podniósł problem szacunków skutków finansowych wejścia w życie projektu ustawy. Premier Oleksy stwierdził wręcz, że „wobec takich skutków finansowych nie ma mowy o wprowadzeniu ustawy i należy ją zdjąć z porządku obrad RM odsyłając go do nowych obliczeń”. Niemniej wywiązała się w tym zakresie zasadnicza dyskusja, w trakcie której przedstawiciele MEN (Kazimierz Przybysz) i NDAP (A. Biernat) nie zgodzili się z reprezentantem MF. Nawet premier zauważył, że przedstawiane przez MF „,wyliczenia skutków finansowych blokują większość inicjatyw ustawodawczych i nie zawsze są realne" ${ }^{99}$. Ostatecznie jednak Rada Ministrów „odroczyła rozpatrzenie projektu ustawy - Prawo archiwalne, decydując o jego ponownym wniesieniu pod obrady Rządu po

${ }^{97}$ AZ NDAP, 486/5 NDAP, WOiP, Notatka Andrzeja Biernata z udziału w posiedzeniu Rady Ministrów w dn. 22 VIII 1995 r., na którym omawiano projekt ustawy - Prawo archiwalne, s. 118.

${ }_{98}$ Ibidem. W trakcie obrad premier Oleksy nie dopuścił do głosu Ministra Obrony Narodowej Zbigniewa Okońskiego.

${ }^{99}$ Ibidem, s. 118-119. 
rozstrzygnięciu rozbieżności dotyczących skutków finansowych wejścia w życie omawianej regulacji”'100.

Dyskusja na posiedzeniu Rady Ministrów nie rozstrzygnęła w żaden sposób sporu dotyczącego likwidacji statusu archiwów państwowych wyodrębnionych. Na dalszym etapie prac nad projektem ustawy, który był oczywiście przedmiotem kolejnych ustaleń i korespondencji (zwłaszcza ze strony Ministerstwa Finansów czy instytucji samorządowych), nie powrócono już do kwestii likwidacji archiwów wyodrębnionych. Sam projekt ustawy - Prawo archiwalne do końca kadencji Sejmu nie był również przedmiotem rozważań Rady Ministrów ${ }^{101}$.

W uzupełnieniu należy dodać, iż w kolejnym projekcie ustawy - Prawo archiwalne z 14 grudnia 1998 r. dalej podtrzymywano stanowisko dotyczące likwidacji archiwów wyodrębnionych, proponując w zamian kategorię archiwów państwowych bieżących, spełniających jednocześnie zadania archiwów historycznych, jednak z nadaniem prawa do nieudostępniania (reglamentowania) materiałów archiwalnych przyjętych dla pozostałych archiwów. Ciekawym zabiegiem było z kolei podkreślenie znaczenia ówczesnych cywilnych służb specjalnych ponieważ - obok Centralnego Archiwum Wojskowego - do projektu ustawy wpisano wprost tzw. Centralne Archiwum Urzędu Ochrony Państwa, nad którym nadzór miał wykonywać Prezes Rady Ministrów w porozumieniu z Naczelnym Dyrektorem. Wprawdzie wpisano również do tego projektu powstający właśnie Instytut Pamięci Narodowej - jako podmiot prowadzący działalność w zakresie państwowego zasobu archiwalnego i wchodzący w skład państwowej sieci archiwalnej - ale nie określono jego zasadniczego statusu. Niemniej projekt ustawy z końca 1998 r., warty z pewnością odrębnego studium analitycznego, również nie wszedł w życie ${ }^{102}$.

\section{Podsumowanie}

W końcu czerwca 1996 odbyła się w Puławach międzynarodowa konferencja archiwalna pod nazwą „Archiwa Europy Środkowej i Wschodniej w dobie przekształceń prawno-ustrojowych", w trakcie której szeroko dyskutowano również kwestie związane z organizacją archiwów i nowych rozwiązań prawnych w zakresie prawa archiwalnego ${ }^{103}$. W jej trakcie J. Skowronek zauważył, że „bardzo ważnym, a trudnym do zrealizowania dążeniem jest zunifikowanie struktury

${ }^{100}$ ARM, 2733/31 URM, Protokół ustaleń nr 31/95 posiedzenia Rady Ministrów w dniach 22 i 23 sierpnia 1995 r., s. 274.

101 A. Biernat, Prawo archiwalne w Polsce - walka o nowa ustawe (ze wspomnień weterana), [w:] Archiwa polskie wczoraj i dziś, red. K. Kozłowski i W. Stępniak, Warszawa 2012, s. 28.

${ }_{102}$ Zob:. Projekt ustawy - Prawo archiwalne, „Archiwista Polski” 1999, nr 1(13), s. 15-30 oraz Uzasadnienie, ibidem, s. 31-35.

${ }^{103}$ Zob.: E. Rosowska, Przekształcenia w zakresie prawa archiwalnego w krajach Europu Środkowej $i$ Wschodniej, ibidem, 1996, nr 3, s. 51-57 oraz B. Woszczyński, Międzynarodowa konferencja archiwalna w Putawach, „Archeion” 1997, t. 97, s. 348-352. 
historycznych archiwów państwowych”. Podkreślił, iż projekt ustawy - Prawo archiwalne proponuje do wyboru dwa rozwiązania w zakresie archiwów wyodrębnionych:

1) „zaakceptowanie przez wszystkie instytucje, posiadające własne wyodrębnione archiwa historyczne, systematycznego, merytorycznego nadzoru inspektorów - archiwistów państwowej służby archiwalnej",

2) „systematyczne przekazywanie zasobu historycznego (30-50 lat po jego wytworzeniu) do Archiwum Akt Nowych w Warszawie, gromadzącego archiwa historyczne władz centralnych".

Wyraził przy tym nadzieję, że powyższe rozwiązania znajdą akceptację władz państwowych i, w ostateczności, nowa ustawa archiwalna zostanie uchwalona przez Sejm ${ }^{104}$.

Z kolei A. Biernat dostrzegł, że miejsce archiwów wyodrębnionych w strukturze państwowej sieci archiwalnej jest „problemem wymagającym prawnego rozwiązania”. Przyznał przy tym, iż „można powiedzieć, że obecnie w Polsce toczy się walka o jednolity system zarządzania państwowymi archiwami bieżącymi, które w całości powinny podlegać nadzorowi państwowej administracji archiwalnej". Takie rozwiązanie miało wprowadzać funkcję kontroli pozaresortowej nad dotychczasowymi archiwami wyodrębnionymi, przy zachowaniu specyfiki tych instytucji. Jak jednak zauważył ,takie rozwiązanie natrafia na opór ze strony właśnie tych instytucji”, a rozstrzygająca decyzja w kwestii archiwów wyodrębnionych ma ,charakter polityczny i leży w gestii Rady Ministrów, a następnie Sejmu" 105 .

Podsumowując to Ewa Rosowska zauważyła, że procesy demokratyzacji instytucji państwowych zachodzące ówcześnie w byłych państwach komunistycznych, w sferze archiwalnej - oprócz nowelizacji lub wprowadzania nowego prawa archiwalnego - wyrażały się również $\mathrm{m}$.in. w „rozszerzeniu sfery uprawnień państwowej służby archiwalnej do nadzoru i kontroli nad archiwami państwa pełniących funkcje ochronno-represyjne i zewnętrzne"106.

$\mathrm{Z}$ drugiej strony, z punktu widzenia archiwów wyodrębnionych, projekt ustawy - Prawo archiwalne z 1995 r. oraz projekty aktów wykonawczych do niej należy ocenić jako ofensywne, szeroko idące, nieuwzględniające hermetyczności tych resortów, a zwłaszcza ówczesnej specyfiki zasobów archiwalnych MSW, które od 1990 r. były przedmiotem burzliwej dyskusji o lustracji. Według ówczesnego MSW, projekt miał charakter zdecydowanie ingerujący już nawet nie $\mathrm{w}$ funkcjonowanie wyodrębnionych archiwów resortowych, lecz w bieżą-

104 J. Skowronek, Zarzadzanie archiwami państwowymi w okresie transformacji ustrojowych $w$ Polsce, [w:] Archiwa Europy Środkowej $i$ Wschodniej $w$ dobie przekształceń prawnoustrojowych. Materiaty międzynarodowej konferencji archiwalnej 28-30 czerwca 1996 r. w Puławach, red. B. Woszczyński przy udziale E. Rosowskiej, Warszawa 1997, s. 119.

105 A. Biernat, Ustawodawstwo..., s. 47-48.

106 E. Rosowska, op.cit., s. 52. 
cą działalność samych organów posiadających takie archiwa (MSW, UOP itd.). Nie ukrywał tego sam Naczelny Dyrektor stanowczo stwierdzając, że dotyczyć on będzie również służb specjalnych, co - jak przykładowo punktowało MSW w kwietniu 1995 r. - mogło teoretycznie prowadzić do prób kontroli sposobu prowadzenia dokumentacji spraw operacyjnych Zarządu Kontrwywiadu UOP przez zewnętrznych kontrolerów.

Nie dziwi zatem absolutnie kategoryczny opór przed wprowadzeniem nowych rozwiązań prawnych w zakresie likwidacji statusu wyodrębnionego ze strony MSW, za którym poszło MON (początkowo również MSZ, które ostatecznie wycofało swój sprzeciw). Ogromna dynamika wydarzeń z wiosny i lata 1995 r. wskazuje ponadto na duże emocje towarzyszące temu procesowi.

Zauważalne jest jednak wzajemne niezrozumienie pomiędzy środowiskami archiwów państwowych a archiwów wyodrębnionych, właściwych zwłaszcza w zakresie bezpieczeństwa wewnętrznego państwa. Ostatecznie należy stwierdzić, iż smutną konstatacją autora niniejszego studium jest fakt istnienia tego wzajemnego niezrozumienia do dziś - 25 lat po podjęciu przez archiwa państwowe bezprecedensowej próby likwidacji statusu wyodrębnionego.

\section{Źródła}

Archiwum Rady Ministrów w Warszawie, 2963/5 Komitet Społeczno-Polityczny Rady Ministrów; 2733/32 Urząd Rady Ministrów; 2880/78 Urząd Rady Ministrów, Sekretariat Rady Ministrów. Naczelna Dyrekcja Archiwów Państwowych, Archiwum Zakładowe, 486/5 Naczelna Dyrekcja Archiwów Państwowych Wydział Organizacji i Planowania.

Druk nr 31 - Przedstawiony przez Prezydenta Rzeczypospolitej Polskiej projekt ustawy o utworzeniu Archiwum Obywatelskiego oraz o powszechnym udostępnianiu dokumentacji wytworzonej w latach 1944-1990 przez organy bezpieczeństwa państwa, http://orka.sejm.gov.pl/ proc3.nsf/opisy/31.htm [dostęp: 19.07.2020].

Druk nr 252 - Rządowy projekt ustawy o Instytucie Pamięci Narodowej, http://orka.sejm.gov.pl/ proc3.nsf/opisy/252.htm [dostęp: 19.072020].

Ustawa z dnia 14 grudnia 1982 r. o ochronie tajemnicy państwowej i służbowej (Dz.U. 1982, nr 40, poz. 271, z późn. zm).

Ustawa z dnia 14 lipca 1983 r. o narodowym zasobie archiwalnym i archiwach (Dz.U. 1983, nr 38, poz. 173, z późn. zm.).

Ustawa z dnia 6 kwietnia 1990 r. o Policji (Dz.U. 1990, nr 30, poz. 179).

Ustawa z dnia 6 kwietnia 1990 r. o Urzędzie Ochrony Państwa (Dz.U. 1990, nr 30, poz. 180).

Ustawa z dnia 6 kwietnia 1990 r. o urzędzie Ministra Spraw Wewnętrznych (Dz.U. 1990, nr 30, poz. 181).

Uchwała Trybunału Konstytucyjnego z dnia 13 VI 1994 r. w sprawie ustalenia powszechnie obowiązującej wykładni art. 2 ust. 1 pkt 2 ustawy z dnia 14 grudnia 1982 r. o ochronie tajemnicy państwowej i służbowej (Dz.U. 1994, nr 74, poz. 336). 
Ustawa z dnia 18 grudnia 1998 r. o Instytucie Pamięci Narodowej - Komisji Ścigania Zbrodni przeciwko Narodowi Polskiemu (Dz.U. 1998, nr 155, poz. 1016, z późn. zm.).

Ustawa $\mathrm{z}$ dnia 2 marca 2007 r. o zmianie ustawy o narodowym zasobie archiwalnym i archiwach (Dz.U. 2007, nr 64, poz. 426).

\section{Bibliografia}

Biernat A., Prawo archiwalne w Polsce - walka o nowa ustawę (ze wspomnień weterana), [w:] Archiwa polskie wczoraj i dziś, red. K. Kozłowski i W. Stępniak, Warszawa 2012, s. 25-35.

Biernat A., Ustawodawstwo archiwalne w świetle przeobrażeń prawnoustrojowych $w$ Polsce, [w:] Archiwa Europy Środkowej $i$ Wschodniej $w$ dobie przekształceń prawnoustrojowych. Materiały międzynarodowej konferencji archiwalnej 28-30 czerwca 1996 r. w Puławach, red. B. Woszczyński przy udziale E. Rosowskiej, Warszawa 1997, s. 45-50.

Borysiuk P., Specyfika funkcjonowania archiwów wyodrębnionych w Polsce - aspekty prawno-historyczne i strukturalne. Zarys problematyki, [w:] Studia. Materiały. Konferencje Stowarzyszenia Archiwistów Polskich, nr 8: Archiwa wyodrębnione w polskiej sieci archiwalnej, red. A. Jabłoński, Szczecin 2020, s. 19-85.

Galuba R., Archiwa wyodrębnione w państwie demokratycznym, [w:] Nowa archiwistyka - archiwa i archiwistyka w ponowoczesnym kontekście kulturowym, Toruńskie konfrontacje archiwalne, t. 4, red. W. Chorążyczewski, W. Piasek i A. Rosa, Torun 2014, s. 119-136.

Galuba R., Archiwa wyodrębnione. Wybór przepisów z lat 2000-2011, Poznań 2013.

Gonzalez Quintana A., Archives of the security services of former repressive regimes. Report prepared for UNESCO on behalf of the International Council of Archives, „Janus” 1998, nr 2, s. $7-25$.

Gonzalez Quintana A., Archives of the security services of former repressive regimes. Report prepared for UNESCO on behalf of the International Council of Archives, Paris 1997, https:// unesdoc.unesco.org/ark:/48223/pf0000140074 [dostęp: 19.072020].

Gonzalez Quintana A., Archival policies in the protection of human rights. An updated and fuller version of the report prepared by UNESCO and the International Council on Archives (1995), concerning the management of the archives of the state security services of former repressive regimes, Paris 2009, https://www.ica.org/sites/default/files/Report_Gonzalez-Quintana EN.pdf [dostęp: 19.07.2020].

Grzelak P., Wojna o lustracje, Warszawa 2005.

Koczwańska-Kalita D., (Nie)chciane dziecko III RP. Instytut Pamięci Narodowej 2000-2010. Geneza, funkcjonowanie, kontekst społeczny i polityczny, Kraków 2015.

Projekt ustawy - Prawo archiwalne, „Archiwista Polski” 1999, nr 1(13), s. 15-30.

Rosowska E., Przekształcenia $w$ zakresie prawa archiwalnego $w$ krajach Europu Środkowej $i$ Wschodniej, „Archiwista Polski” 1996, nr 3, s. 51-57.

Skowronek J., Zarzadzanie archiwami państwowymi w okresie transformacji ustrojowych w Polsce, [w:] Archiwa Europy Środkowej i Wschodniej w dobie przekształceń prawnoustrojowych. Materiały międzynarodowej konferencji archiwalnej 28-30 czerwca 1996 r. w Puławach, red. B. Woszczyński przy udziale E. Rosowskiej, Warszawa 1997, s. 117-120. 
Stępniak W., UNESCO na rzecz dostępu obywateli do akt tajnych stużb państw represyjnych, „Archiwista Polski” 2000, nr 2(18), s. 51-56.

Uzasadnienie, „Archiwista Polski” 1999, nr 1(13), s. 31-35.

Woszczyński B., Międzynarodowa konferencja archiwalna w Puławach, „Archeion” 1997, t. 97, s. $348-352$.

Woszczyński B., Rada Archiwalna kadencji 1995-1997, „Archeion”, 1998, t. 99, s. 339-345. 